\title{
Methanol production from Refuse Derived Fuel: Influence of feedstock composition on process yield through gasification analysis
}

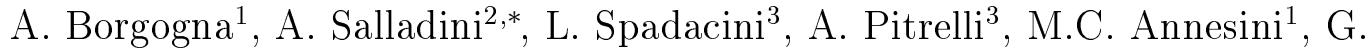 \\ Iaquaniello ${ }^{2}$
}

\section{Abstract}

Currently the production of methanol from Refuse Derived Fuel, a derived product of Municipal Solid Waste, can be deemed as an excellent example of circular economy, by representing a promising alternative both to conventional methods of waste disposal and methanol production from fossil resources. High-temperature conversion of waste in syngas is the main step of the Waste-to-Methanol process. Unfortunately, produced syngas does not directly comply with the requirements for methanol synthesis, in that syngas purification and conditioning steps are required. Moreover, waste, due to its heterogeneous nature, presents a variable composition, leading to the production of variable syngas flowrate and composition. A thermodynamic equilibrium model of gasification unit has been developed in Aspen Plus environment and applied to analyse the effects of feedstock variability; RDF composition has been characterized considering as main parameters: ash, moisture and combustible fractions, carbon to hydrogen and carbon to oxygen ratios, and Lower Heating Value. Then, a simplified simulation of downstream process has been introduced to evaluate the influence

\footnotetext{
*Corresponding author

Email address: A.Salladini@NextChem.it (A. Salladini)

${ }^{1}$ Department of Chemical Engineering Materials Environmental, University of Rome "La Sapienza" Via Eudossiana 18, 00184 Rome, Italy

${ }^{2}$ NextChem s.r.l., Via di Vannina 88, 00156 Rome, Italy

${ }^{3}$ OESA s.r.l., Via Pontina 545, 00128 Rome, Italy
} 
of waste composition on overall methanol production. The present study allows the identification of the main parameters affecting the syngas and, accordingly, overall process yield, consumptions and emissions.

Keywords: Waste to Methanol, Refuse Derived Fuel, Gasification, Feed sensitivity, Aspen Plus simulation

\section{Introduction}

In the last decades, political and social efforts have been made towards the replacement of fossil fuels with renewable energy sources in order to reduce the environmental impact associated with power generation and chemicals synthesis; in fact, the use of renewable sources allows the reduction of the $\mathrm{CO}_{2}$ emissions and therefore contributes positively in the direction of not increasing the greenhouse effect. The European Commission supports this trend through the Renewable Energy Directive (2009/28/EC) that establishes the year 2020 as a deadline to achieve mandatory targets consistent with $20 \%$ share of renewable sources in the overall energy consumption of the Community, as well as 10\% share of advanced biofuels in the transport sector. Within the same directive, the employment of second-generation biomass is promoted by limiting up to $7 \%$ the contribution of advanced biofuels derived from food-crops and by counting twice the contribution of advanced biofuels produced from waste, residues, non-food cellulosic or lignocellulosic material. Indeed, considering also the indirect environmental impact, especially Green House Gases (GHG) emissions linked to land use, biofuels produced from food-crops could even have a higher impact than those derived from fossil resources (Lapola et al., 2010, Swain et al. 2011). Although research is ongoing to reduce this impact, for example improving processes and reducing the amount of biomass feedstock required Maroušek 
et al. 2018b), fuel or chemical production from waste can represent a valid alternative to conventional processes for waste disposal or chemical production. Moreover, valorization of waste for chemical production perfectly fits with the Circular Economy concept, which promotes a social tendency to a closed loop economic and production model by encouraging the most efficient use of products and the reuse of residual sources (Ghisellini et al., 2016). There are several possible pathways for waste conversion and valorisation (Matsakas et al., 2017); an example could be the use of waste material to produce charcoal which can be used to enrich lignocellulosic material for solid biofuel production (Hašková, 2017). The employment of Municipal Solid Waste (MSW) or Refuse Derived Fuel (RDF), a MSW derived product (with higher heating value), for chemical production provides an innovative and clever strategy to overcome the shortcomings associated with traditional waste management, a problem that is particularly felt in Italy (Senior and Mazza, 2004, Agovino et al., 2016). Thermochemical conversion, pyrolysis or gasification, of MSW seems to be the most appealing method for biofuel production from waste. Pyrolysis allows the production of gaseous and liquid products that can be further processed in order to produce biofuel; and also the solid residue obtained from pyrolysis (biochar) has been discovered having several uses and applications. (Maroušek et al. 2018a, Mardoyan and Braun, 2015, Bergfeldt et al., 2018). In this work we will focus on a particular gasification process. Traditional waste treatments, such as landfill and incineration, could ensure only a partial energy recovery, while thermal gasification provides several advantages in terms of flexibility and versatility, by allowing the production of syngas that can be used both for power generation (with a controlled combustion) and chemicals production (Consonni and Viganò, 2012).

In particular, a Waste to Chemical (WtC) process appears as an attractive perspective from environmental, social and economic standpoints and seems to be more ad- 
vantageous with respect to a Waste to Energy (WtE) process in terms of emissions and therefore on climate changes (Aracil et al. 2017). Some industrial applications in this direction have been already carried out or are planned for the next few years. An industrial application is provided by methanol and ethanol production from nonrecyclable urban residue in Edmonton, Canada, by Enerkem Alberta Biofuel, producing on the whole about $38 \cdot 10^{6} \mathrm{~L}$ of biofuel per year (Enerkem s.r.l.). The process is based on waste conversion through a Bubbling Fluidised bed gasifier, working at temperature near to $800{ }^{\circ} \mathrm{C}$. By 2020, jet biofuel should be produced in Nevada, Sierra Biofuel plant through Fischer Tropsch process from syngas produced from waste (Fulcrum Bioenergy). Thermal converting technology will be a steam-reforming gasifier produced by ThermoChem Recovery International. One of the benefit of this technology is that, by introducing steam, syngas clean-up starts directly inside the reactor. Plasma Enhanced Melter is an other kind of gasification technology industrially applied for waste conversion. The provider of this plasma technology is planning to produce ethanol from syngas coming from waste (InEnTec). An advantage of this technology, is the high temperature reached, which allows the collection of not-organic fraction of waste directly as inert vitrified material. Another gasification technology called High temperature and direct melting furnace, provides the same advantage of producing a vitrified material through melting process of ash fraction of waste; moreover, this technology is also able to produce a good-quality syngas due to the introduction of further oxidant agent in the upper section of the reactor. By evaluating a suitable process scheme, including the last mentioned gasification technology, the sustainability and economic feasibility of urea or methanol production from RDF has been demonstrated (Iaquaniello et al., 2017; Antonetti et al., 2017).

Among other opportunities, methanol production from waste appears particularly interesting from the economic and technical points of view (Iaquaniello and Salladini, 
2017). Briefly, methanol is easy to store, avoiding dependence from market trends; it is a flexible product used both as building block for various chemical productions (dimethyl ether, formaldehyde or acid acetic and others) and as transport fuel, especially since the above cited EU directive incentives; finally, it is also deemed as a promising energy/hydrogen carrier, as demonstrated by recent efforts in Direct Methanol Fuel Cell development research (Gallucci et al., 2007).

A detailed analysis of the Waste to Methanol (WtM) process, has been reported by Iaquaniello et al. 2017 (Iaquaniello et al., 2017); in this paper, the authors consider an RDF composed of wood, paper, plastic, textile, organic fraction and inert fraction fed to a WtM process. It is worth noting that, while in the WtE plant the syngas composition can vary in quite a wide range of values, without any problematic consequences, a proper composition of the gas fed to the catalytic reactor for methanol production is required. Indeed, methanol can be obtained from syngas according to the following chemical reactions:

$$
\begin{aligned}
& \text { Reaction I: } \mathrm{CO}+2 \mathrm{H}_{2} \longleftrightarrow \mathrm{CH}_{3} \mathrm{OH} \\
& \text { Reaction II: } \quad \mathrm{CO}_{2}+3 \mathrm{H}_{2} \longleftrightarrow \mathrm{CH}_{3} \mathrm{OH}+\mathrm{H}_{2} \mathrm{O}
\end{aligned}
$$

The suitability of syngas composition to methanol synthesis is usually expressed in terms of the Methanol Module (MM) value, defined as

$$
M M=\frac{\left(\mathrm{H}_{2}-\mathrm{CO}_{2}\right)}{\left(\mathrm{CO}+\mathrm{CO}_{2}\right)}
$$

According to stoichiometry, a MM value of 2 is required; taking into account industrial experiences a value of MM equal to 2.1 should be adopted (Rostrup-Nielsen, 2000 Shahhosseini et al. 2018). Moreover, a proper water content is required to control the catalyst activity: more specifically, a low water content should be maintained in the reactor to avoid catalyst deactivation. Correspondingly, the $\mathrm{CO}_{2}$ content has 
to be controlled: if it is too high, excessive water production from reaction II is promoted and catalyst deactivation occurs; instead, if the $\mathrm{CO}_{2}$ content is too low, the catalyst activity is too high and the outlet temperature increase too much. Therefore, a syngas with a water content lower than $0.05 \%$, a carbon ratio (CR), defined as $\mathrm{CO}_{2} /\left(\mathrm{CO}+\mathrm{CO}_{2}\right)$, between 0.2 and 0.5 , and $\mathrm{CO}_{2}$ content lower than $12 \%$ is considered as suitable for the industrial production of methanol Grabow and Mavrikakis 2011) . As matter of fact, in order to achieve this syngas composition, a conditioning system is required in the WtM process.

Thermodynamic equilibrium model is an useful tool to predict the influence of the above parameters affecting gasification perfomances (Patra and Sheth, 2015). It is well known that syngas flowrate and composition depend on the gasifier configuration, gasifying agent and operating conditions, such as temperature and pressure (Gagliano et al., 2017; Mahishi and Goswami, 2007), and also on the fuel type (Ramzan et al., 2011). Indeed, the fuel type affects gasification performances through its physical and chemical characteristics, such as particle size, porosity or chemical composition de Souza-Santos, 2010). With regard to the influence of chemical composition, in the case of biomass gasification, the effects of the moisture content (Couto et al. 2013 Zainal et al., 2001) and the carbon to hydrogen $(\mathrm{C} / \mathrm{H})$ and carbon to oxygen $(\mathrm{C} / \mathrm{O})$ ratios (Schuster et al., 2001) have been investigated. As regards waste, performances of plasma gasification of MSW through a thermodynamic analysis have been evaluated (Zhang et al., 2012, 2013). Furthermore, to the best of our knowledge, the effect of feedstock, MSW from Thailand, composition on gasification performance has been investigated only as regard moisture content, thus neglecting the impact of overall waste composition (Jarungthammachote and Dutta, 2007). In the specific case of RDF gasification, it is worth noting that the MSW composition varies in a range wider than that reported for biomass, and depends on many technical and social pa- 
rameters (Beigl et al. 2008); as a consequence, the composition of the RDF obtained from MSW via a defined biological and mechanical treatment, is also variable, even if within a narrower range. In what follows, we show that other parameters characterizing the feedstock may have sizeable effect on the gasification process. The aim of this work is to develop a systematic analysis on the effect of variability of the overall waste composition on the gasification process. Furthermore, this analysis is not limited to the gasification step, but also extends to the assessment of the performance of methanol production by post-treatments of the syngas effluent. The paper is organized as follows: firstly, we analyse the RDF composition in terms of combustible fraction, moisture content and ash fraction, as well as in terms of elemental composition of the combustible fraction, in order to identify a significant range of RDF compositions; in the second part, we present a kinetic free model relevant to the core unit of the WtM process, i.e. the RDF gasification unit, that allows to evaluate the effect of the RDF composition variability on the syngas composition; finally, in the third part of the paper we model the whole WtM process evaluating the effect of the RDF composition variability on the methanol yield, process consumptions and emissions.

\section{Material and Method}

\subsection{RDF characterization}

As underlined in the Introduction, the RDF exhibits an inherent composition variability, depending on the solid waste composition (organic waste, synthetic materials, paper/cardboards, ceramic materials, glass, etc.), which, in turn, depends on the selection procedure, season (variable atmospheric condition), geographical location, etc. Even when the mechanical and biological treatments applied to RDF production result in an RDF composition varying in a narrower range than that of the MSW, RDF' $s$ range is still wide enough to affect both the syngas composition obtained 
from the gasifier and the downstream process required for methanol synthesis.

In detail, RDF composition can be described considering three main pseudo-components: combustible fraction (CHO), moisture (MOI) and a residual (Ash\&OC) fraction; the latter one includes ash and other waste components, i.e. chlorine, nitrogen and sulphur, which have a minor relevance in our study due to their low contents (in this study they have been considered as fixed quantities, i.e. $\mathrm{Cl}_{\mathrm{w}}=0.75 \%, \mathrm{~S}_{\mathrm{w}}=0.15 \%$, and $\mathrm{N}_{\mathrm{w}}=1 \%$ (wet basis)). As reported in Table 1, the combustible fraction (CHO) is the most abundant fraction (about 50-80\% by weight), while the moisture and the residual fraction both range between $10 \%$ and $25 \%$. On the other hand, the specific composition of combustible fraction, i.e. carbon, hydrogen and oxygen contents, is also significant. In particular, characterization studies (Pohl et al., 2008; Beckmann et al., 2012 ) report that the $\mathrm{C} / \mathrm{H}$ ratio (mass basis) in the combustible fraction varies between 7 and 8; while, the $\mathrm{C} / \mathrm{O}$ ratio (mass basis) spreads in a wider range (1-4), as depicted in Fig. 1. (a). In this figure, combustible fraction compositions deriving from literature data (Akdağ et al., 2016; Montejo et al., 2011; Hajinezhad et al., 2016; Lin et al. 1999: Galvagno et al., 2006) and from the analysis of RDF collected in a facility situated in Rome, are also reported. The $\mathrm{CHO}$ and moisture content strongly affect the RDF heating value, which can be evaluated from several empirical correlations reported in the literature (Hittinger, 1988). In this work, we evaluate the Higher Heating Value (HHV) and Lower Heating Value (LHV) according to the relation (Institute of Gas Technology, 1978) :

$\mathrm{HHV}_{\mathrm{w}}\left[\mathrm{MJ} \mathrm{kg}^{-1}\right]=0.3417 \mathrm{C}_{\mathrm{w}}+1.3221 \mathrm{H}_{\mathrm{w}}+0.1232 \mathrm{~S}_{\mathrm{w}}-0.1198\left(\mathrm{O}_{\mathrm{w}}+\mathrm{N}_{\mathrm{w}}\right)-0.0153 \mathrm{Ash}_{\mathrm{w}}$ $\mathrm{LHV}_{\mathrm{w}}\left[\mathrm{MJ} \mathrm{kg}^{-1}\right]=\mathrm{HHV}_{\mathrm{w}}-0.121 \mathrm{H}_{\mathrm{w}}-0.0245 \mathrm{MOI}-0.0008 \mathrm{O}_{\mathrm{w}}$

where $\mathrm{C}_{\mathrm{w}}, \mathrm{H}_{\mathrm{w}}, \mathrm{O}_{\mathrm{w}}, \mathrm{N}_{\mathrm{w}}, \mathrm{S}_{\mathrm{w}}$, and $\mathrm{Ash}_{\mathrm{w}}$ are the mass fractions of the different components on wet basis. 
On the basis of these correlations, in Fig 1-(b) the waste LHV has been reported for three different values of the $\mathrm{C} / \mathrm{O}$ ratio as a function of $\mathrm{CHO}$, MOI and Ash\&OC fractions; the coloured areas represent LHV values between 14 and $18 \mathrm{MJ} \mathrm{kg}^{-1}$, the points depicted as ' represent the punctual LHV values of an RDF sample collected in the Italian facility with a value of the $\mathrm{C} / \mathrm{O}$ ratio close to the one highlighted in each panel. As shown in this figure, if the combustible fraction and the moisture content are fixed, in the range of $\mathrm{C} / \mathrm{H}$ and $\mathrm{C} / \mathrm{O}$ in which $\mathrm{RDF}$ composition is supposed to vary, the $\mathrm{RDF}$ lower heating value is mainly dependent on the $\mathrm{C} / \mathrm{O}$ ratio of the combustible fraction.

It is worth noting that the Lower Heating Value is often considered as a useful supplementary parameter for RDF characterization; furthermore, depending on the RDF LHV, the WtE and WtM processes can be classified as a disposal method, with a possible economic support.

In particular, in our analysis we will consider RDF with a LHV ranging between 14 and $18 \mathrm{MJ} \mathrm{kg}^{-1}$.

\subsection{Gasification unit model}

In order to evaluate the effect of the RDF composition on the syngas composition, we refer to a high temperature thermogasification unit, with direct melting of inert fraction, schematically described in Fig, 2 a. Such a reactor is capable of gasifying and melt the feeding waste, which has a high ash content, thus allowing for the simultaneous production of an inert slag and a syngas stream. The gasifier works close to atmospheric pressure and at high temperature. The latter ranges from about $1600^{\circ} \mathrm{C}$ in the melting zone near the bottom of the gasifier, to $600-800^{\circ} \mathrm{C}$ in the gasification zone and, again, up to $1100^{\circ} \mathrm{C}$ in the stabilization zone, near the top of the gasifier. This temperature profile is maintained by two series of burners, the first one near the gasifier bottom and the second one in the upper part of the gasifier (see Fig. 2 a). 


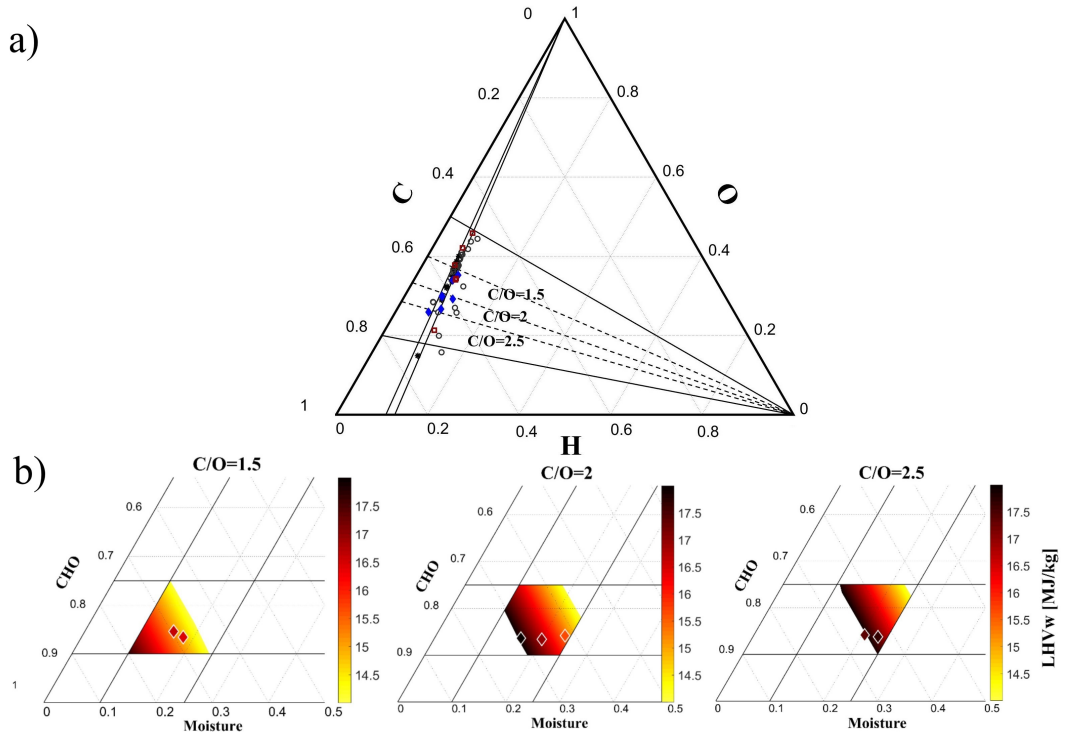

Figure 1: a) Representation in a ternary diagram of $\mathrm{C} \%, \mathrm{H} \%$ and $\mathrm{O} \%$ of different waste samples:' data from the Italian facility; '*' data from characterization work of Pohl et al. (Pohl et al., 2008); ' '' data from Phyllis database (Energy research Centre of the Netherlands), including some RDF sample with an high plastic content; ' $\square$ literature data (Akdağ et al. 2016; Montejo et al., 2011; Hajinezhad et al., 2016; Lin et al. 1999, Galvagno et al., 2006) ; b) Waste LHV represented in a ternary diagram as a function of $\mathrm{CHO}, \mathrm{MOI}$ and $\mathrm{Ash} \& \mathrm{OC}$ fractions at different values of $\mathrm{C} / \mathrm{O}$ ratio.

The high temperature condition and the hot-syngas quench technology, consisting of freezing the composition near to the gasifier top, allow, respectively, to achieve full tar degradation and to avoid dioxin reformation, thus facilitating the downstream cleaning operation (McKay, 2002; Devi et al., 2003).

It is well known that many chemical reactions occur in the gasifier, some of which are summarized in Table 2. In this work, a thermodynamic or kinetic-free model, developed in Aspen Plus environment, useful for a preliminary evaluation of the syngas composition obtained from the gasifier, is presented. Indeed, in the gasification/combustion field, the thermodynamic equilibrium approach is a customary analysis, suitable for the evaluation of thermal efficiency, maximum yield of desired product, and optimization of operating conditions (Patra and Sheth, 2015; Gagliano et al., 2017; Mahishi 
Table 1: Typical range of RDF composition.

\begin{tabular}{|c|c|c|}
\hline $\mathrm{CHO}$ & MOI & Ash\&OC \\
\hline $50-80 \% \mathrm{RDF}$ & $10-25 \% \mathrm{RDF}$ & $10-25 \% \mathrm{RDF}$ \\
\hline \multicolumn{3}{|l|}{$\mathrm{CHO}$} \\
\hline \multicolumn{3}{|l|}{$\mathrm{C} / \mathrm{H}=7.5$} \\
\hline $\mathrm{C} / \mathrm{O}=1.5$ & $\mathrm{C} / \mathrm{O}=2$ & $\mathrm{C} / \mathrm{O}=2.5$ \\
\hline $\mathrm{C}_{\mathrm{w}}=0.56 \mathrm{CHO}$ & $\mathrm{C}_{\mathrm{w}}=0.61 \mathrm{CHO}$ & $\mathrm{C}_{\mathrm{w}}=0.65 \mathrm{CHO}$ \\
\hline $\mathrm{H}_{\mathrm{w}}=0.07 \mathrm{CHO}$ & $\mathrm{H}_{\mathrm{w}}=0.08 \mathrm{CHO}$ & $\mathrm{H}_{\mathrm{w}}=0.09 \mathrm{CHO}$ \\
\hline $\mathrm{O}_{\mathrm{w}}=0.37 \mathrm{CHO}$ & $\mathrm{O}_{\mathrm{w}}=0.31 \mathrm{CHO}$ & $\mathrm{O}_{\mathrm{w}}=0.26 \mathrm{CHO}$ \\
\hline
\end{tabular}

\section{Ash composition}

\begin{tabular}{l}
\hline \hline $\mathrm{SiO}_{2}=0.36 \mathrm{Ash}_{\mathrm{w}}$ \\
\hline $\mathrm{CaO}=0.36 \mathrm{Ash}_{\mathrm{w}}$ \\
\hline $\mathrm{Al}_{2} \mathrm{O}_{3}=0.13 \mathrm{Ash}_{\mathrm{w}}$ \\
\hline $\mathrm{Fe}_{2} \mathrm{O}_{3}=0.15 \mathrm{Ash}_{\mathrm{w}}$ \\
\hline \hline
\end{tabular}

and Goswami, 2007; Jarungthammachote and Dutta, 2007). The thermodynamic equilibrium condition is obtained by direct minimization of the Gibbs free energy, under the constraint of the balance of the chemical elements. In this way, the definition of the reactions occurring in the reactor is not required, but only the chemical identification of the potential species in the exiting stream must be defined. In this work we assume that $\mathrm{H}_{2}, \mathrm{CO}, \mathrm{CO}_{2}, \mathrm{H}_{2} \mathrm{O}, \mathrm{O}_{2}, \mathrm{HCl}, \mathrm{H}_{2} \mathrm{~S}, \mathrm{COS}, \mathrm{N}_{2}, \mathrm{Ar}, \mathrm{NO}_{2}, \mathrm{Cl}_{2}, \mathrm{CH}_{4}$, S and $\mathrm{C}$ can be obtained.

The RDF is here modelled as a non-conventional component with a known ultimate analysis; the ash has been supposed to be composed of $\mathrm{SiO}_{2}, \mathrm{CaO}, \mathrm{Al}_{2} \mathrm{O}_{3}$ and $\mathrm{Fe}_{2} \mathrm{O}_{3}$, with a known weight fraction composition indicated in Table 1. Ash heat capacity and latent heat of fusion have been estimated using the method proposed by Mills (Mills, 1986). 
Once the waste composition has been defined, the LHV was estimated from the above mentioned correlation (Institute of Gas Technology, 1978) and the HCOALGEN property model was used to evaluate the enthalpy variation of formation $\Delta H_{f}$ as well as the heat capacity of waste. This model has been developed for the estimation of the properties of coal but is appropriate also in the cases of biomass and waste, as shown in previous works (Ramzan et al., 2011; Doherty et al., 2013; Begum et al., 2014). The gasifier has been modelled through four reactor blocks, an RYIELD and three RGIBBS block, as reported in the scheme of Fig. 2 b.

In details:

- The RYIELD block is a fictitious block, aiming at a proper definition of mass and heat balance, required to reproduce the waste decomposition step (and related heat required), and to define the elemental composition of the stream fed to the RGIBBS blocks. It is fed with the RDF, modelled as non-conventional component, as previously described, and with a small amount of inert gas $\left(\mathrm{N}_{2}\right)$, reproducing the amount required for the inertization of the feeding chamber. The RDF was then decomposed in the its elemental components $(\mathrm{C}, \mathrm{H}, \mathrm{O}, \mathrm{Cl}, \mathrm{S}$ and $\mathrm{N}$ ).

- The outlet stream from the RYIELD reactor was divide into two streams, $75 \%$ was fed to the RGIBBS2 and $25 \%$ to the RGIBBS1. In the same way, the heat duty related to the RYIELD was divided and loaded to the RGIBBS2 and RGIBBS1. This approach, adopted in the literature to model biomass gasification, allows to include into the heat balance of the gasification process the energy required to break chemical bonds (Ramzan et al., 2011; Begum et al., 2014).

- The melting zone was represented by the Gibbs reactor RGIBBS1, heated via the introduction of methane and pure oxygen. A fixed flowrate of oxygen and 
methane was assumed; the temperature was controlled at $1600^{\circ} \mathrm{C}$ by introducing an additional oxygen stream, while a heat loss of $1.2 \mathrm{MW}$ was considered on the basis of experience from full scale plants. Peng-Robinson thermodynamic model has been used in this reactor, as well as in the RGIBBS2 and RGIBBS3.

- The gasification zone, where the gasification reactions occur without further introduction of any oxidizing agent, was modelled in the RGIBBS2 block, fed with a part $(75 \%)$ of the stream from the RYIELD and with the gas from the RGIBBS1. The unreacted carbon (due to the low temperature) and ashes were fed to the RGIBBS1 while gas was fed to the RGIBBS3. Temperature in this reactor was obtained from the heat balance, where a heat loss of $0.5 \mathrm{MW}$ was accounted for on the basis of experience from industrial scale plants; the result was a temperature ranging about $650^{\circ} \mathrm{C}$ and $750^{\circ} \mathrm{C}$.

- The stabilization zone was modelled in the RGIBBS3. Here, the temperature was also set to $1100^{\circ} \mathrm{C}$ and controlled by manipulating the feed flowrate of oxygen and methane (molar ratio $\mathrm{O}_{2} / \mathrm{CH}_{4}=4$ ).

- The raw syngas, obtained as the output of the gasification reactor, was quickly cooled in the quench section to freeze its composition. It was subjected to a pre-cleaning step consisting of acid and alkaline scrubbers. Each of these steps had been evaluated by taking into account only of the water removal and had been simulated with three flash blocks. The last flash, which mainly defines the final syngas composition, worked a temperature of about $40^{\circ} \mathrm{C}$. An ideal thermodynamic model, with Henry's constants obtained from the Aspen Database was used for all these blocks. Table 3 summarize the operating conditions used in the simulation, referred to an RDF feed flow rate of $8 \mathrm{t} \mathrm{h}^{-1}$; in the same table, the ranges of oxygen flow rate to the burners (calculated to obtain the set 
temperatures in RGIBBS1 and RGIBBS3) are reported.

Here, we investigate the effect of the RDF composition on the gasifier performance and on the efficiency of the WtM process, referring to a range of RDF feedstock defined as:

- $\mathrm{C} / \mathrm{H}$ ratio of $\mathrm{CHO}$ fraction equal to 7.5

- $\mathrm{C} / \mathrm{O}$ ratio of $\mathrm{CHO}$ fraction equal to 1.5, 2, and 2.5;

- Combustible, moisture and residual fractions variable in the range 50-80\%, 10 $25 \%$ and $10-25 \%$, respectively;

- LHV between 14 and $18 \mathrm{MJ} \mathrm{kg}^{-1}$.

Table 2: Gasification process main reactions.

\begin{tabular}{ll}
\hline \hline Carbon combustion & $\mathrm{C}+\mathrm{O}_{2} \longrightarrow \mathrm{CO}_{2}$ \\
\hline Boudouard reaction & $\mathrm{C}+\mathrm{CO}_{2} \longleftrightarrow 2 \mathrm{CO}$ \\
\hline Steam gasification & $\mathrm{C}+\mathrm{H}_{2} \mathrm{O} \longleftrightarrow \mathrm{CO}+\mathrm{H}_{2}$ \\
\hline Methanation & $\mathrm{C}+2 \mathrm{H}_{2} \longleftrightarrow \mathrm{CH}_{4}$ \\
\hline Water gas shift & $\mathrm{CO}+\mathrm{H}_{2} \mathrm{O} \longleftrightarrow \mathrm{CO}_{2}+\mathrm{H}_{2}$ \\
\hline COS formation & $\mathrm{CO}+\mathrm{S} \longleftrightarrow \mathrm{COS}$ \\
\hline \hline
\end{tabular}

\subsection{Conditioning and methanol synthesis model}

To complete our study, we report a preliminary investigation on the whole process for the methanol production starting from RDF feedstock. The process scheme considered is the one suggested by Iaquaniello et al. (Iaquaniello et al., 2017). Here the enhancement of syngas MM up to 2.1 is obtained by two steps: the syngas is first sent to a shift reactor to convert $\mathrm{CO}$ to $\mathrm{CO}_{2}$, thus increasing $\mathrm{H}_{2}$; in the second step, $\mathrm{CO}_{2}$ is removed via amine absorption. In detail, we try to evaluate the methanol yield based on the waste composition. Following the results previously discussed, 
Table 3: Gasification unit operation conditions.

\begin{tabular}{|c|c|c|c|}
\hline RDF Flowrate [ton $\mathrm{h}^{-1}$ ] & \multicolumn{2}{|l|}{8} & Input \\
\hline Pressure [bar] & \multicolumn{2}{|c|}{1.2} & Input \\
\hline \multirow{2}{*}{ Oxygen specifications } & $\mathrm{O}_{2}$ & $95 \% \mathrm{~mol}$ & \multirow{2}{*}{ Input } \\
\hline & $\mathrm{Ar}$ & $5 \% \mathrm{~mol}$ & \\
\hline \multicolumn{4}{|l|}{ Melting zone } \\
\hline Temperature $\left[{ }^{\circ} \mathrm{C}\right]$ & \multicolumn{2}{|c|}{1600} & Input(Controlled variable) \\
\hline \multirow{2}{*}{ Burners Flowrate $\left[\mathrm{kg} \mathrm{h}^{-1}\right]$} & ${ }^{(1)} \mathrm{O}_{2}+\mathrm{CH}_{4}$ & 900 & Input \\
\hline & $\mathrm{O}_{2}$ & $2280-3160$ & Output(Manipulated variable) \\
\hline \multicolumn{4}{|l|}{ Gasification zone } \\
\hline Temperature $\left[{ }^{\circ} \mathrm{C}\right]$ & \multicolumn{2}{|c|}{$655-740$} & Output \\
\hline \multicolumn{4}{|l|}{ Stabilization zone } \\
\hline Temperature $\left[{ }^{\circ} \mathrm{C}\right]$ & \multicolumn{2}{|c|}{1100} & Input(Controlled variable) \\
\hline Burners Flowrate $\left[\mathrm{kg} \mathrm{h}^{-1}\right]$ & ${ }^{(1)} \mathrm{O}_{2}+\mathrm{CH}_{4}$ & $1220-1690$ & Output(Manipulated variable) \\
\hline
\end{tabular}

(1) Molar ratio $\mathrm{O}_{2} / \mathrm{CH}_{4}=4$

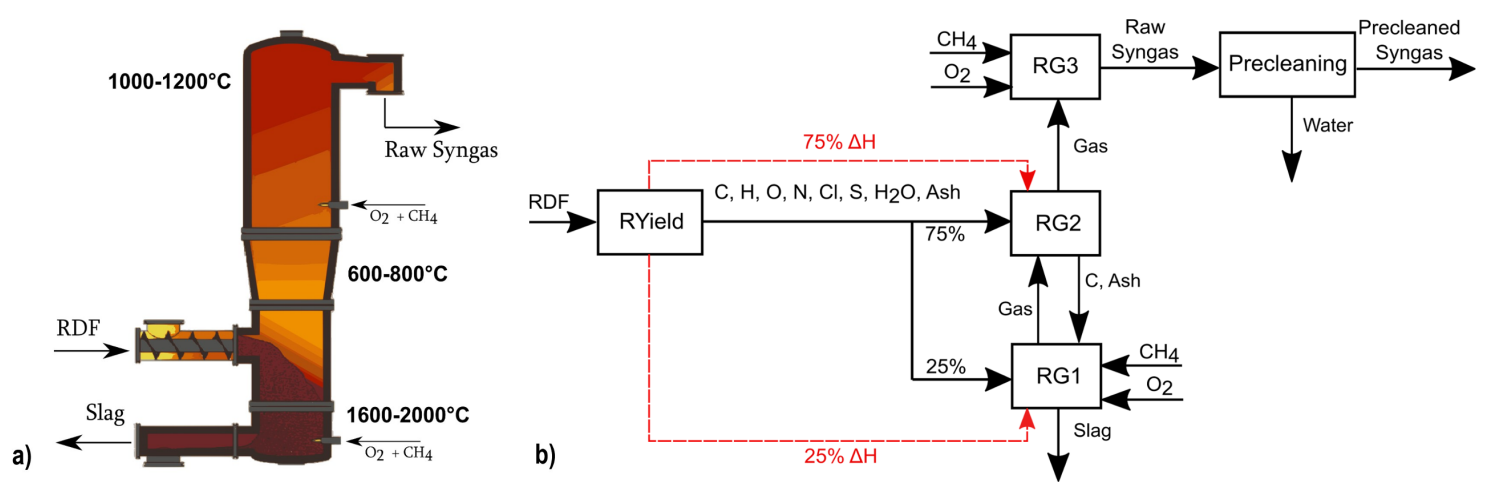

Figure 2: a) Section view of gasification reactor; b) Block scheme of built-in model developed in Aspen Plus environment.

we consider the mean syngas compositions, corresponding to three different values of RDF LHV (14, 16, and $\left.18 \mathrm{MJ} \mathrm{kg}^{-1}\right)$, for each C/O ratio (1.5, 2, and 2.5) here considered. As a case study, we assume a steam to dry syngas ratio of $1.5\left(\mathrm{~mol} \mathrm{~mol}^{-1}\right)$ and a feed temperature of $320^{\circ} \mathrm{C}$, for the shift reactor, as required for catalyst activation. This reactor is simulated as a Gibbs reactor operating at adiabatic conditions; due 


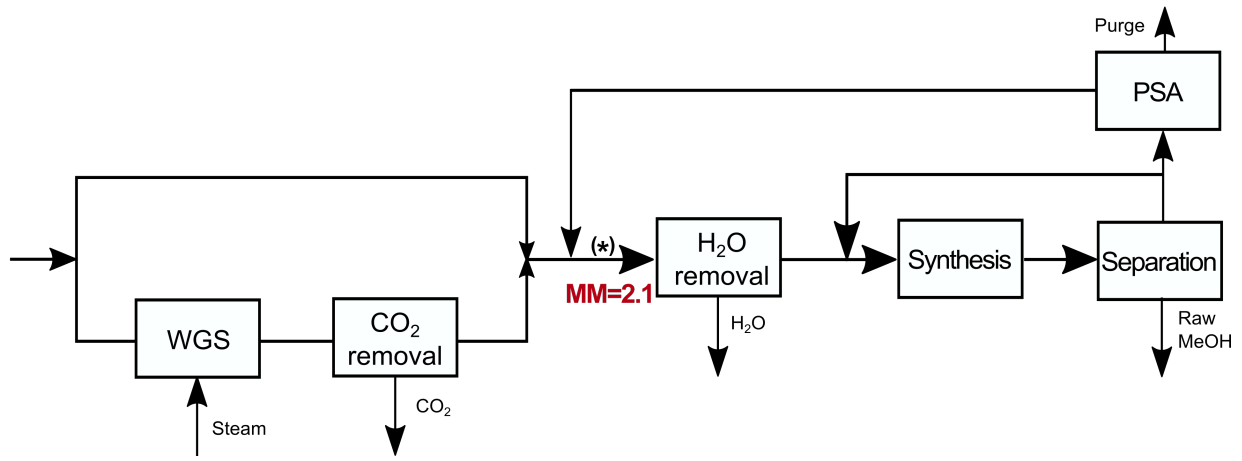

Figure 3: Block diagram scheme of conditioning and methanol synthesis steps ('*' see Table 5).

to the exothermicity of the Water Gas Shift (WGS) reaction the converted stream temperature is near to $470^{\circ} \mathrm{C}$. The shift reaction increases the $\mathrm{CR}$ up to a value near 0.9, too high for methanol synthesis, while the MM remains unchanged. In our process scheme, a $\mathrm{CO}_{2}$ separation unit able to remove $95 \%$ of the $\mathrm{CO}_{2}$ is included; in this way the MM grows, while the $\mathrm{CO}_{2}$ content and $\mathrm{CR}$ decreases. Hence, to obtain the correct composition required for methanol synthesis (specifically in order to have $\mathrm{MM}=2.1$ ) has to be sent to the conditioning unit (Fig. 3 ).

After water removal through condensation, the obtained stream is suitable for methanol synthesis. In this case, an isothermal Gibbs reactor, operating at 51.8 barg and temperature of $270^{\circ} \mathrm{C}$ has been considered in the simulation. Methanol and water are recovered from the outlet stream through a condensation step at $30^{\circ} \mathrm{C}$ and 51.4 barg; due to the low per pass conversion, the gaseous phase, with a hydrogen content of about $85 \%$, is recycled in the synthesis reactor in order to increase the whole conversion of the synthesis process. A purge of $3.5 \%$ of the gaseous stream is assumed, to avoid the build-up of non-reacting compounds in the reactor. A further separation unit, via Pressure Swing Adsorption (PSA) (see scheme in Fig.3), is provided in order to recover pure $\mathrm{H}_{2}$ which can be mixed with the conditioned syngas, thus reducing the capability of the conditioning unit. 
Table 4: Conditioning unit operation conditions.

\begin{tabular}{|c|c|c|}
\hline \multicolumn{3}{|l|}{ High temperature shift } \\
\hline Pressure [barg] & 12.6 & Input \\
\hline Inlet temperature $\left[{ }^{\circ} \mathrm{C}\right]$ & 320 & Input \\
\hline \multicolumn{3}{|l|}{ Adiabatic condition } \\
\hline Outlet temperature $\left[{ }^{\circ} \mathrm{C}\right]$ & $460-480$ & Output \\
\hline Steam introduction $\left[\right.$ ton $_{\text {steam }}$ ton $_{\left.\mathrm{RDF}^{-1}\right]}$ & $0.823-0.963$ & Output \\
\hline \multicolumn{3}{|l|}{$\mathrm{CO}_{2}$ absorption } \\
\hline $\mathrm{CO}_{2}$ separation specification & $95 \%$ & Input \\
\hline \multicolumn{3}{|l|}{ Methanol synthesis reactor } \\
\hline Pressure [barg] & 51.8 & Input \\
\hline Temperature $\left[{ }^{\circ} \mathrm{C}\right]$ & 270 & Input \\
\hline \multicolumn{3}{|l|}{ Isothermal condition } \\
\hline \multicolumn{3}{|l|}{ Pressure Swing Adsorption } \\
\hline $\mathrm{H}_{2}$ separation specification & $85 \%$ & Input \\
\hline
\end{tabular}

\section{Results and discussion}

The proposed model allows to evaluate the influence of the RDF characteristics on the composition of the syngas obtained from the gasifier.

Before proceeding with a detailed analysis of the simulation results, a preliminary comparison of the simulation model results with full-scale experimental data was carried out to test the reliability of the model. To this aim, we referred to the composition of the raw and cleaned syngas obtained from OESA industrial units. Even if, for such a plant, the feed variability does not allow to have an RDF composition corresponding to a defined raw and cleaned syngas, spot sampling analysis of the RDF fed to the plant showed that the ash content varies between 10 and $20 \%$ and LHV between 15 and $18 \mathrm{MJ} \mathrm{kg}^{-1}$. Therefore, we simulate the gasifier behaviour for a feed composition varying in the range previously reported and compare the raw and cleaned syngas compositions with the measured value ranges. A summary of the 
results obtained is reported in Fig. 4; the figure shows a satisfactory agreement between simulation results (coloured bars) and measured data (black lines), thus supporting the reliability of the proposed model.

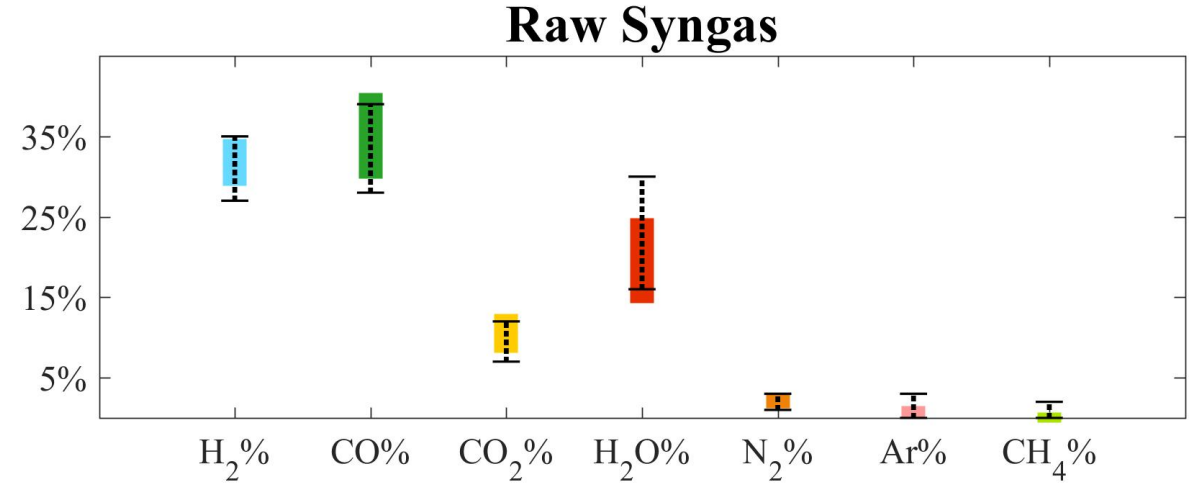

Cleaned Syngas

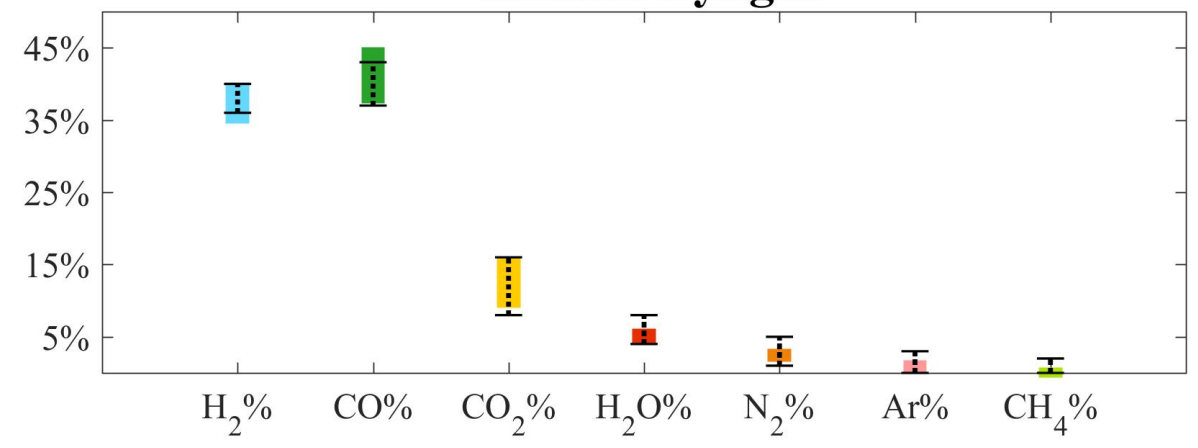

Figure 4: Comparison between data resulting from simulation (coloured bars) and measured plant data (black lines) both for syngas directly produced by gasification unit (Raw Syngas) and for the cleaned one (Cleaned Syngas).

In order to go deeply into the analysis of the influence of the RDF composition on the syngas composition, we analyse the dependence of the syngas flowrate and composition on the combustible fraction and moisture content of the RDF. As previously reported, for each pair of combustible and moisture fractions, three different $\mathrm{C} / \mathrm{O}$ ratios in the combustible fraction were considered, while the RDF compositions resulting in LHVs out of the range 14-18 $\mathrm{MJ} \mathrm{kg}^{-1}$ were discarded. 
Observing results, it can be gathered that an increase in ash amount entails a decrease in the $\mathrm{H}_{2}$ and $\mathrm{CO}$ content and an increase in the $\mathrm{CO}_{2}$ content. This behaviour is due to the increase of the required heat for ash melting, which is supplied by strongly exothermic reactions, i.e. $\mathrm{H}_{2}$ and $\mathrm{C}$ combustion. As a result, the whole system reclaims more oxygen and produces more $\mathrm{CO}_{2}$. The moisture content has a double effect on the syngas composition. First, similarly to the ash content, the heat required by the process increases with the water content, both as sensible and latent heat. Secondly, since water is not an inert component, it affects the equilibrium of the gasification reactions, producing more $\mathrm{H}_{2}$. As a result of these two opposite effects, the $\mathrm{H}_{2}$ content shows a non-linear behaviour. Predictably, the higher the combustible fraction of waste the higher is the syngas flowrate. Ternary diagram, which can be found in the supplementary material section, where the $\mathrm{H}_{2} \%, \mathrm{CO} \%, \mathrm{CO}_{2} \%$ and syngas flowrate are plotted as a function of combustible, moisture and residual contents, can be helpful to directly visualize the described behaviour.

Since RDF is usually characterized by its LHV, both from a regulatory and an economic point of view, we attempt to evaluate whether the RDF LHV can be considered as the main parameter for the evaluation of plant performance. For this purpose, for a $\mathrm{C} / \mathrm{O}$ ratio of 2 , the syngas composition and flowrate have been reported as functions of LHV in Fig. 5. The figure shows that while the hydrogen and carbon monoxide content span over quite a wide range of values at fixed LHV, both the syngas flow rate and the carbon dioxide content are strictly correlated to the RDF lower heating value.

As previously reported, the syngas composition suitable for methanol synthesis is usually expressed in terms of Methanol Module (MM), moisture content and carbon ratio $(\mathrm{CR})$ : in details a $\mathrm{MM}$ of 2.1 , a moisture content lower than $0.05 \%$ and a $\mathrm{CR}$ $\left(\mathrm{CO}_{2} /\left(\mathrm{CO}+\mathrm{CO}_{2}\right)\right)$ between 0.2 and 0.5 are required for methanol synthesis. There- 
fore, the MM and CR have also been calculated from the simulation results and are plotted as a function of the RDF LHV, in Fig. 5(ternary diagram of the same values are also supplied in the supplementary material section). From the plot, it is evident that the MM and CR vary with RDF composition: while the CR is within or very near to the acceptable range, the MM is always significantly lower than the required value. Moreover, the MM is strongly dependent on the LHV of waste, which in turn is related to the combustible content. Therefore, in view of the use of syngas for methanol production, we can conclude that the LHV of RDF can be considered as a leading parameter for a streamlined downstream process design and characterization. Nevertheless, looking at Table 5, the influence of $\mathrm{C} / \mathrm{O}$ ratio on syngas composition and flowrate must be also accounted for.

In this framework, it is also important to underline that since the syngas composition, at fixed LHV and $\mathrm{C} / \mathrm{O}$ ratio, varies in quite a wide range depending on the RDF composition, a deeper analysis based on the complete characterization of waste, as the one performed in this work, should be carried out for process definition steps that require a higher degree of detail.

In any case, all these results indicate that, regardless of the RDF composition, a conditioning step is needed if the syngas, coming from the high temperature gasifier here analysed, has to be use for methanol production.

Furthermore, we have to highlight intrinsic limits of thermodynamic approach. As for comparison with experimental measurements, syngas composition flowing from gasifier is satisfactory predicted by our model. Anyway further work aimed at developing a model including kinetic and transport phenomena occurring in the gasifier should be required in order to built knowledge as regard the dynamic response of the system to the operating conditions and feedstock parameters variability. Compositions and flowrates of syngas from the gasification and conditioning units are 

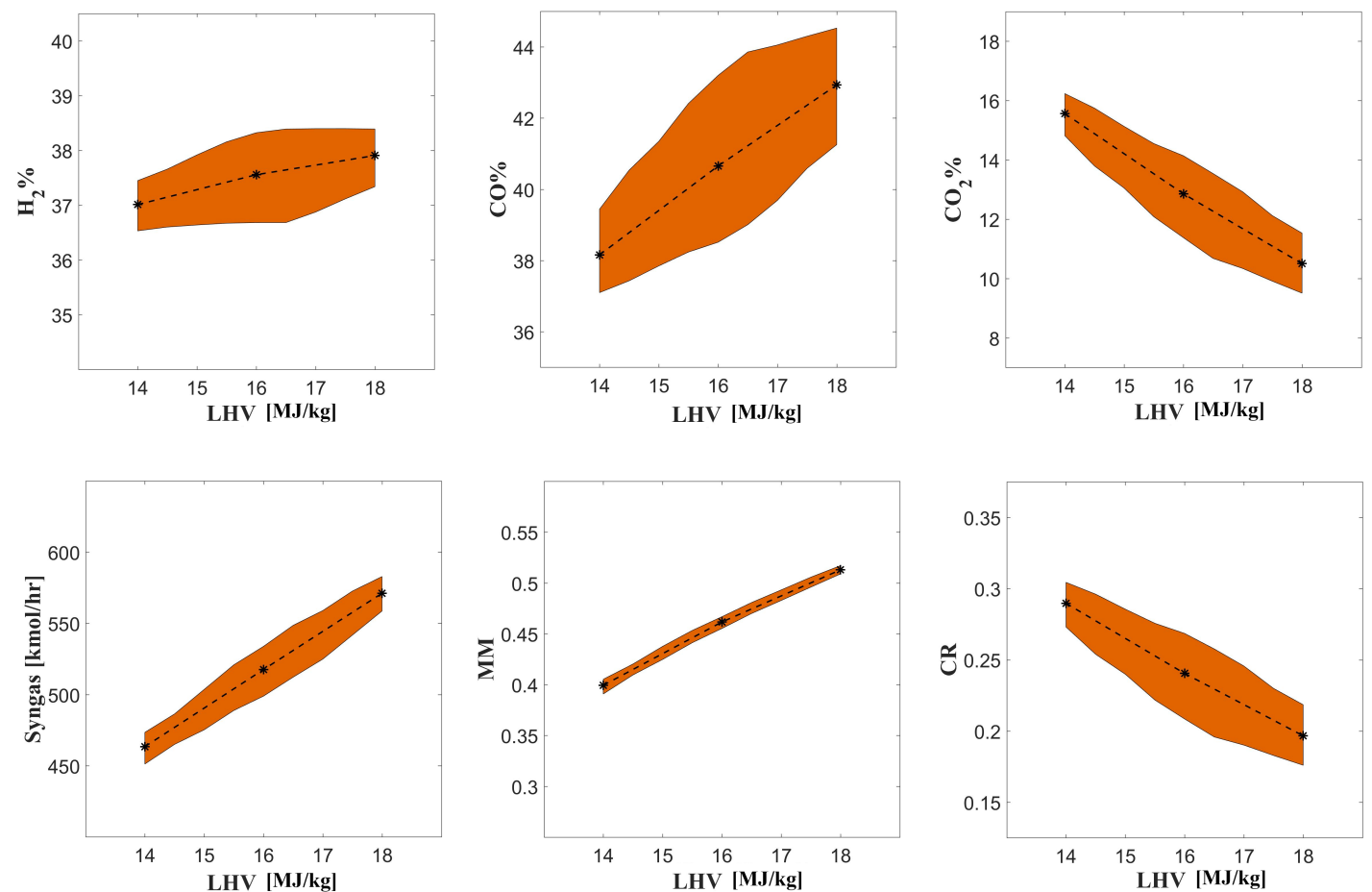

Figure 5: $\mathrm{H}_{2} \%, \mathrm{CO} \% \mathrm{CO}_{2} \%$, syngas flowrate, $\mathrm{MM}$ and $\mathrm{CR}$ values, resulting from simulations, represented in a ternary diagram as function of waste related LHV; in the case of $\mathrm{C} / \mathrm{O}$ ratio equal to 2 . 
Table 5: Specifications of syngas from gasification unit and conditioned one ('*' see Fig.6).

\begin{tabular}{|c|c|c|c|c|c|c|c|c|}
\hline $\mathrm{C} / \mathrm{O}$ ratio & \multicolumn{2}{|c|}{1.5} & \multicolumn{3}{|c|}{2} & \multicolumn{3}{|c|}{2.5} \\
\hline $\mathrm{LHV}_{\mathrm{RDF}}$ & 14 & 16 & 14 & 16 & 18 & 14 & 16 & 18 \\
\hline \multicolumn{9}{|c|}{ Syngas from gasification unit } \\
\hline $\begin{array}{l}\mathrm{H}_{2} \% \\
(\min -\max )\end{array}$ & $\begin{array}{c}35.5 \% \\
34.5-36.4\end{array}$ & $\begin{array}{c}36.0 \% \\
35.5-36.4\end{array}$ & $\begin{array}{c}37.0 \% \\
36.5-37.5\end{array}$ & $\begin{array}{c}37.5 \% \\
36.7-38.3\end{array}$ & $\begin{array}{c}37.9 \% \\
37.3-38.4\end{array}$ & $\begin{array}{c}37.8 \% \\
37.6-38.0\end{array}$ & $\begin{array}{c}38.4 \% \\
37.9-38.9\end{array}$ & $\begin{array}{c}38.8 \% \\
37.9-39.5\end{array}$ \\
\hline $\begin{array}{l}\mathrm{CO} \% \\
(\min -\max )\end{array}$ & $\begin{array}{c}39.5 \% \\
37.0-42.2\end{array}$ & $\begin{array}{c}42.1 \% \\
40.7-43.4\end{array}$ & $\begin{array}{c}38.2 \% \\
37.1-39.7\end{array}$ & $\begin{array}{c}40.9 \% \\
38.5-43.5\end{array}$ & $\begin{array}{c}43.0 \% \\
41.3-44.5\end{array}$ & $\begin{array}{c}37.5 \% \\
37.0-38.1\end{array}$ & $\begin{array}{c}39.8 \% \\
39.5-41.5\end{array}$ & $\begin{array}{c}42.0 \% \\
39.7-44.6\end{array}$ \\
\hline $\begin{array}{l}\mathrm{CO}_{2} \% \\
(\min -\max )\end{array}$ & $\begin{array}{c}15.8 \% \\
14.2-17.3 \\
\end{array}$ & $\begin{array}{c}13.0 \% \\
12.2-13.9 \\
\end{array}$ & $\begin{array}{c}15.5 \% \\
14.6-16.3 \\
\end{array}$ & $\begin{array}{c}12.7 \% \\
11.1-14.1 \\
\end{array}$ & $\begin{array}{c}10.5 \% \\
9.5-11.5 \\
\end{array}$ & $\begin{array}{c}15.4 \% \\
15.0-15.8 \\
\end{array}$ & $\begin{array}{c}12.8 \% \\
11.7-13.7 \\
\end{array}$ & $\begin{array}{c}10.4 \% \\
8.9-11.8 \\
\end{array}$ \\
\hline $\begin{array}{l}\text { MM } \\
(\min -\max )\end{array}$ & $\begin{array}{c}0.36 \\
0.35-0.36\end{array}$ & $\begin{array}{c}0.42 \\
0.41-0.42\end{array}$ & $\begin{array}{c}0.40 \\
0.39-0.41\end{array}$ & $\begin{array}{c}0.46 \\
0.45-0.47\end{array}$ & $\begin{array}{c}0.51 \\
0.51-0.52\end{array}$ & $\begin{array}{c}0.42 \\
0.42-0.43\end{array}$ & $\begin{array}{c}0.49 \\
0.48-0.50\end{array}$ & $\begin{array}{c}0.54 \\
0.53-0.55\end{array}$ \\
\hline $\begin{array}{l}\text { CR } \\
(\min -\max )\end{array}$ & $\begin{array}{c}0.29 \\
0.25-0.32\end{array}$ & $\begin{array}{c}0.24 \\
0.22-0.26\end{array}$ & $\begin{array}{c}0.29 \\
0.27-0.31\end{array}$ & $\begin{array}{c}0.24 \\
0.20-0.27\end{array}$ & $\begin{array}{c}0.20 \\
0.18-0.22\end{array}$ & $\begin{array}{c}0.29 \\
0.28-0.30\end{array}$ & $\begin{array}{c}0.24 \\
0.22-0.26\end{array}$ & $\begin{array}{c}0.20 \\
0.20-0.17\end{array}$ \\
\hline $\begin{array}{l}\text { Flowrate [kmol } \\
\left.\mathbf{h}^{-1}\right] \\
(\min -\max )\end{array}$ & $\begin{array}{c}465 \\
447-483\end{array}$ & $\begin{array}{c}519 \\
505-531\end{array}$ & $\begin{array}{c}462 \\
451-473\end{array}$ & $\begin{array}{c}516 \\
499-534\end{array}$ & $\begin{array}{c}570 \\
545-583\end{array}$ & $\begin{array}{c}461 \\
454-470\end{array}$ & $\begin{array}{c}516 \\
503-530\end{array}$ & $\begin{array}{c}570 \\
551-589\end{array}$ \\
\hline $\begin{array}{l}\text { Split fraction } \\
\text { of conditioned } \\
\text { stream }\end{array}$ & 0.59 & 0.58 & 0.57 & 0.57 & 0.55 & 0.56 & 0.55 & 0.53 \\
\hline \multicolumn{9}{|c|}{ Syngas after conditioning $(*)$} \\
\hline $\mathrm{H}_{2} \%$ & $66.5 \%$ & $66.4 \%$ & $66.5 \%$ & $66.4 \%$ & $66.4 \%$ & $66.5 \%$ & $66.5 \%$ & $66.3 \%$ \\
\hline $\mathrm{CO} \%$ & $19.6 \%$ & $21.3 \%$ & $19.5 \%$ & $21.5 \%$ & $22.7 \%$ & $19.4 \%$ & $21.0 \%$ & $22.6 \%$ \\
\hline $\mathrm{CO}_{2} \%$ & $8.1 \%$ & $7.0 \%$ & $8.2 \%$ & $6.8 \%$ & $6.1 \%$ & $8.3 \%$ & $7.2 \%$ & $6.1 \%$ \\
\hline MM & 2.1 & 2.1 & 2.1 & 2.1 & 2.1 & 2.1 & 2.1 & 2.1 \\
\hline CR & 0.29 & 0.25 & 0.30 & 0.24 & 0.21 & 0.30 & 0.25 & 0.21 \\
\hline $\begin{array}{l}\text { Flowrate [kmol } \\
\text { ton }_{\mathrm{RDF}^{-1}}{ }^{-1}\end{array}$ & 56.5 & 64.0 & 56.4 & 65.2 & 71.2 & 56.5 & 63.9 & 71.4 \\
\hline
\end{tabular}

summarized in Table 5. The fraction of the raw syngas that has to be sent to conditioning unit ranges from $53 \%$ to $59 \%$, depending on the waste heating value. The higher the RDF LHV and C/O ratio, the lower the fraction of syngas to be sent to the conditioning.

Table 6 summarized the main products, by-products and consumptions of the overall 
process, referred to 1 ton of RDF converted. A methanol yield ranging from $44.7 \%$ to $59.0 \%$ (ton of pure methanol per ton of RDF) was obtained; the higher the LHV, the higher the methanol yield; the $\mathrm{C} / \mathrm{O}$ ratio does not have a significant influence on this value. The consumptions spanned within moderate ranges: $\mathrm{O}_{2}$ between $0.56-0.64$ $\left[\operatorname{ton}_{\mathrm{O}_{2}} \operatorname{ton}_{\mathrm{RDF}}{ }^{-1}\right]$; steam, used for high temperature shift, between 0.82-0.99 [ton ${ }_{\text {steam }}$ ton $_{\mathrm{RDF}}{ }^{-1}$. We also estimate the mass of $\mathrm{CO}_{2}$ corresponding to the carbon content captured in the produced methanol; this value can be referred as " $\mathrm{CO}_{2}$ avoided" since it corresponds to the $\mathrm{CO}_{2}$ that would be emitted in the atmosphere if the syngas were burned rather than used for methanol synthesis. This value also varied in

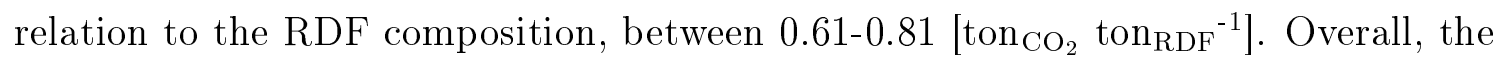
process yield was influenced mainly by the waste LHV, and ranged between $44.4 \%$ to $59 \%$.

In table 7 we also consider energy streams entering in the system, starting from energy associated to the $\mathrm{RDF}$ and $\mathrm{CH}_{4}$, the last one considered having a LHV equal to $50 \mathrm{MJ} \mathrm{\textrm {kg } _ { \mathrm { CH } }}{ }^{-1}$. Energy related to steam introduced in the conditioning section has been taken into account considering an enthalpy value of $2.8 \mathrm{MJ} \mathrm{kg}_{\text {steam }}{ }^{-1}$. Finally, we consider energy introduced in the system as power: one contribution comes from the power required for $\mathrm{O}_{2}$ production $\left(0.5 \mathrm{MWh}\right.$ ton $\left._{\mathrm{O}_{2}}{ }^{-1}\right)$; the other contribution comes directly from the power required for compression units. The overall energy required for the production of one ton of methanol (E1) has been calculated accounting for the yield values reported in 6 . Also in this case, $\mathrm{C} / \mathrm{O}$ ratio is not influencing results, on the contrary LHV of waste does: the higher the waste LHV the lower the further energy contribution from other sources for methanol production. E2 represents the overall energy requirement. The feedstock fed to the process was excluded from the evaluation because, if not utilised, it would have to be disposed of. However, waste could be disposed with an energy recover, so in E3 we consider 
Table 6: Consumptions, by-products and products of overall process.

\begin{tabular}{|c|c|c|c|c|c|c|c|c|}
\hline $\mathrm{C} / \mathrm{O}$ ratio & \multicolumn{2}{|c|}{1.5} & \multicolumn{3}{|c|}{2} & \multicolumn{3}{|c|}{2.5} \\
\hline LHV $_{\text {RDF }}$ & 14 & 16 & 14 & 16 & 18 & 14 & 16 & 18 \\
\hline $\begin{array}{l}\mathrm{O}_{2} \text { consumption }\left[\operatorname{ton}_{\mathrm{O}_{2}} \text { ton }_{\mathrm{RDF}^{-1}} \text { (gasification unit) }\right.\end{array}$ & 0.562 & 0.579 & 0.585 & 0.605 & 0.625 & 0.598 & 0.620 & 0.642 \\
\hline $\begin{array}{l}\mathrm{CH}_{4} \text { consumption [ton } \mathrm{CH}_{4} \text { ton }_{\mathrm{RDF}^{-1}} \text { ] } \\
\text { (gasification unit) }\end{array}$ & 0.033 & 0.032 & 0.034 & 0.033 & 0.032 & 0.035 & 0.033 & 0.032 \\
\hline $\begin{array}{l}\text { Steam consumption }\left[\text { ton }_{\text {steam }} \text { ton }_{\mathbf{R D F}^{-1}}\right] \\
\text { (MP-WGS reactor) }\end{array}$ & 0.877 & 0.954 & 0.841 & 0.949 & 0.990 & 0.823 & 0.894 & 0.963 \\
\hline Slag [ton slag $_{\text {ton }}$ & 156 & .117 & 0.198 & 0.1 & 0.130 & 0.218 & 0.184 & 0.153 \\
\hline $\mathrm{CO}_{2}$ recovered [ton $\mathrm{CO}_{2}$ ton $_{\left.\mathrm{RDF}^{-1}\right]}$ & 0.724 & 0.776 & 0.676 & 0.762 & 0.777 & 0.653 & 0.699 & 0.742 \\
\hline $\mathrm{CH}_{3} \mathrm{OH} \%\left[\mathrm{~mol} \mathrm{~mol}^{-1}\right]$ & 75.1 & 78.0 & 74.9 & 78.5 & 80.5 & 74.8 & 77.6 & 80.3 \\
\hline $\mathrm{CH}_{3} \mathrm{OH}$ yield [ton $\mathrm{C}$ ] & 0.447 & 0.520 & 0.445 & 0.5 & 0.591 & 0.444 & 0.517 & 0.590 \\
\hline $\mathrm{CO}_{2}$ avoided [ton $\mathrm{CO}_{2}$ ton $_{\left.\mathrm{RDF}^{-1}\right]}$ & 0.614 & 0.715 & 0.611 & 0.731 & 0.813 & 0.611 & 0.711 & 0.812 \\
\hline
\end{tabular}

the energy that could be recovered as a fictitious further energy stream introduced in the system, a mean value of $21 \%$ of energy efficiency for a Waste to Energy process (Di Maria et al. 2016) has been taken into account. Also observing trend of E3 value, the higher the LHV the lower the "effective" energy consumption.

Economic feasibility of the WtM process has been evaluated in a previous work by Iaquaniello et al. (2017). Cost of production (COP) of methanol has been calculated for an Italian site with capacity of 300 ton $\mathrm{d}^{-1}$ of methanol which correspond to the conversion of 714 ton $\mathrm{d}^{-1}$ of waste with LHV equal to $14 \mathrm{MJ} \mathrm{kg}^{-1}$, resulting equal to $111 €$ ton $_{\mathrm{CH}_{3} \mathrm{OH}^{-1}}$. Taking into account a methanol price of $400 €$ ton $^{-1}$, Return of Investment (ROI) and payback period result, respectively, $28.7 \%$ and 4 years. 
Table 7: Entering energy streams (per ton of RDF), and energy consumptions (per ton of methanol).

\begin{tabular}{|c|c|c|c|c|c|c|c|c|}
\hline $\mathrm{C} / \mathrm{O}$ ratio & \multicolumn{2}{|c|}{1.5} & \multicolumn{3}{|c|}{2} & \multicolumn{3}{|c|}{2.5} \\
\hline LHV $_{\text {RDF }}$ & 14 & 16 & 14 & 16 & 18 & 14 & 16 & 18 \\
\hline $\begin{array}{l}\mathbf{R D F}\left[\mathbf{M J} \text { ton }_{\mathbf{R D F}}{ }^{-\mathbf{1}} \text { ] }\right. \\
\text { (gasification unit) }\end{array}$ & 14000 & 16000 & 14000 & 16000 & 18000 & 14000 & 16000 & 18000 \\
\hline $\begin{array}{l}\mathbf{C H}_{\mathbf{4}}\left[\mathbf{M J} \text { ton }_{\mathbf{R D F}}{ }^{-1}\right] \\
\text { (gasification unit) }\end{array}$ & 1663 & 1600 & 1700 & 1631 & 1575 & 1725 & 1669 & 1613 \\
\hline $\begin{array}{l}\left.\text { Steam [MJ } \text { ton }_{\mathbf{R D F}}{ }^{-\mathbf{1}}\right] \\
\text { (MP-WGS reactor) }\end{array}$ & 2455 & 2672 & 2354 & 2658 & 2771 & 2305 & 2503 & 2696 \\
\hline $\begin{array}{l}\mathrm{O}_{2}\left[\mathbf{M J} \text { ton }_{\mathbf{R D F}}{ }^{-1}\right] \\
\text { (gasification unit) }\end{array}$ & 1011 & 1043 & 1052 & 1088 & 1125 & 1077 & 1116 & 1155 \\
\hline $\begin{array}{l}\left.\text { Power [MJ } \text { ton }_{\mathbf{R D F}}{ }^{\mathbf{- 1}}\right] \\
\text { (compressors) }\end{array}$ & 2548 & 2759 & 2554 & 2786 & 2917 & 2554 & 2755 & 2959 \\
\hline E1 [MJ ton $\mathrm{CH}_{3} \mathrm{OH}^{-1}$ ] & 9684 & 12510 & 9630 & 12843 & 15608 & 9622 & 12427 & 15597 \\
\hline $\mathrm{E} 2\left[\mathrm{MJ}\right.$ ton $_{\left.\mathrm{CH}_{3} \mathrm{OH}^{-1}\right]}$ & 3430 & 4195 & 3406 & 4339 & 4961 & 3403 & 4157 & 4972 \\
\hline E3 [MJ ton $\left.\mathrm{CH}_{3} \mathrm{OH}^{-1}\right]$ & 4743 & 5942 & 4713 & 6124 & 7197 & 4709 & 5894 & 7203 \\
\hline
\end{tabular}




\section{1. $\mathrm{CO}_{2}$ production and emission analysis}

The value of $\mathrm{CO}_{2}$ avoided provides a straightforward and simple interpretation of the $\mathrm{CO}_{2}$ savings which can allow the operation of the WtM process. In the following, we set out a simplified analysis to attain a preliminary outcome as regards the $\mathrm{CO}_{2}$ emissions comparison between the WtE process and the WtM process. First of all, it must be considered that if waste is employed to produce energy (WtE case) the same waste cannot be used for methanol production and thus the amount of methanol, that could have been produced from RDF, will be instead produced by conventional processes. Likewise, in the WtM case, there is an amount of energy that will not be produced by the WtE process but by conventional ones. Accordingly, for the same cases corresponding to LHV 14 - 16 - $18 \mathrm{MJ} \mathrm{kg}^{-1}$ and C/O ratio 1.5 - 2 - 2.5, we evaluate:

- WtE $\mathrm{CO}_{2}$ production as the sum of

- $\mathrm{CO}_{2}$ emissions of the process itself, provided by the conversion of all carbon contained in the RDF and $\mathrm{CH}_{4}$ used in the auxiliary burners during combustion (i.e. the $\mathrm{CH}_{4}$ amount equivalent to the $10 \%$ of energy value of RDF converted);

and, $\mathrm{CO}_{2}$ equivalent emissions for fugitive $\mathrm{CH}_{4}$;

- $\mathrm{CO}_{2}$ emissions relative to the amount of methanol that could be produced with 1 ton of RDF, taking into account the yields resulting from the previous analysis, and the mean value of $\mathrm{CO}_{2}$ production for 1 ton of methanol produced with a conventional process, equal to $0.76\left[\operatorname{ton}_{\mathrm{CO}_{2}} \operatorname{ton}_{\mathrm{CH}_{3} \mathrm{OH}}{ }^{-1}\right]$ (Pérez-Fortes et al., 2016);

and equivalent $\mathrm{CO}_{2}$ from fugitive $\mathrm{CH}_{4}\left(\mathrm{CH}_{4}\right.$ amount employed has been estimated from material balance). 
- WtM $\mathrm{CO}_{2}$ production as the sum of

- $\mathrm{CO}_{2}$ emissions of the process itself, which are equal to sum of $\mathrm{CO}_{2}$ for power and steam production, and that deriving from combustion of the purge. Indeed, taking into account the energy recovery from purge combustion and heat recovery of the overall process, we can consider only the $\mathrm{CO}_{2}$ and $\mathrm{CH}_{4}$ related to the production of power and $68 \%$ of the steam (medium pressure - MP) required for the high temperature shift; the remaining $32 \%$ and the steam required for the amine separation system can be recovered from the process; as for the previous cases, we also account for the fugitive $\mathrm{CH}_{4}$; finally, to the overall sum, it is also added the $\mathrm{CO}_{2}$ removed through the amine separation unit, based on the worst and hypothetical assumption that the $\mathrm{CO}_{2}$ recovered cannot be economically exploited in different applications;

- $\mathrm{CO}_{2}$ emission coming from the conventional production of power, which would be generated by a WtE process using 1 ton of RDF; for such calculation a mean energy efficiency of WtE systems equal to $21 \%$ has been considered (Di Maria et al., 2016); assuming power production from $\mathrm{CH}_{4}$ employment, the $\mathrm{CO}_{2}$ equivalent of fugitive $\mathrm{CH}_{4}$ has been added to the estimated final value.

Other assumptions applied in this analysis are:

- Specific $\mathrm{CO}_{2}$ emission, for a conventional power production, average emission of gas turbines using natural gas, equal to $0.4\left[\operatorname{ton}_{\mathrm{CO}_{2}} \mathrm{MWh}^{-1}\right]$ has been considered (Rubin et al. 2007); 
- $\mathrm{CO}_{2}$ emission for production of 1 ton of MP steam equal to $0.174\left[\operatorname{ton}_{\mathrm{CO}_{2}}\right.$ ton $_{\text {steam }^{-1}}{ }^{\text {, }}$ evaluated taking into account steam production from natural gas through a boiler with a $90 \%$ thermal efficiency;

- Fugitive $\mathrm{CH}_{4}$ percentage equal to $2.5 \%$ and a $\mathrm{CO}_{2}$ equivalent value for $\mathrm{CH}_{4}$ equal to 28 (Intergovernmental Panel on Climate Change, 2014).

Considering all listed items, the overall emission of $\mathrm{CO}_{2}$ for 1 ton of RDF converted related to the WtE or WtM process are exhibit in Table 8 , with the $\%$ of $\mathrm{CO}_{2}$ savings evaluated as

$$
\frac{C O_{2 W t E}-C O_{2 W t M}}{C O_{2 W t E}} \%
$$

As can be gathered, the higher the quality of the waste, i.e. higher calorific value, the higher is the saving in terms of $\mathrm{CO}_{2}$ emissions.

In the framework of a green process, we can make the assumption of using power coming from renewable resources; in this way, in the case of a WtM plant, we can set to zero the $\mathrm{CO}_{2}$ emissions for the required power. The same for methanol which comes from conventional process: we do not consider indirect emissions, which just derive from power consumption and are equal to $10 \%$ of the total emissions (PérezFortes et al., 2016). With this assumption, in the absence of any $\mathrm{CO}_{2}$ valorisation can be gathered an average savings value of $35 \%$, higher than the one referred to the base case equal to $14 \%$, see Table 8 . Moreover, as underlined earlier, these results are related to a conservative assumption, i.e. the emission of the overall $\mathrm{CO}_{2}$ recovered from amine separation unit. Instead, once it has been separated, $\mathrm{CO}_{2}$ can be allocated, even with a revenue, for further utilization (De Falco et al. 2013). On this basis, it should be evident that the \% $\mathrm{CO}_{2}$ saving increases when an amount of the recovered $\mathrm{CO}_{2}$ is valorised. This can be gathered from Fig. 6, which shows, both in the base case and the "green" case, the 
average values of $\mathrm{CO}_{2}$ savings $\%$ and the related minimum and maximum values. Observing the trends of minimum and maximum values, it can be highlighted that the higher the amount of $\mathrm{CO}_{2}$ valorised, the lower is the influence of waste quality on the $\mathrm{CO}_{2}$ savings, mostly in the "green" case.

Table 8: $\mathrm{CO}_{2}$ related to waste conversion in the cases of WtE and WtM processes; $\mathrm{CO}_{2} \%$ savings.

\begin{tabular}{|c|c|c|c|c|c|c|c|c|}
\hline $\mathrm{C} / \mathrm{O}$ ratio & \multicolumn{2}{|c|}{1.5} & \multicolumn{3}{|c|}{2} & \multicolumn{3}{|c|}{2.5} \\
\hline LHV & 14 & 16 & 14 & 16 & 18 & 14 & 16 & 18 \\
\hline $\mathrm{CO}_{2 \mathrm{WtE}}\left[\operatorname{ton}_{\mathrm{CO}_{2}}\right.$ ton $\left.\mathrm{RDF}^{-1}\right]$ & 2.01 & 2.28 & 1.96 & 2.24 & 2.49 & 1.93 & 2.19 & 2.46 \\
\hline $\mathrm{CO}_{2 \mathrm{WtM}}\left[\operatorname{ton}_{\mathrm{CO}_{2}}\right.$ ton $\left._{\mathrm{RDF}^{-1}}\right]$ & 1.80 & 1.95 & 1.75 & 1.95 & 2.05 & 1.73 & 1.88 & 2.02 \\
\hline $\mathrm{CO}_{2} \%$ savings & $10 \%$ & $14 \%$ & $10 \%$ & $13 \%$ & $18 \%$ & $10 \%$ & $14 \%$ & $18 \%$ \\
\hline Average & & & & & & & & $14 \%$ \\
\hline
\end{tabular}

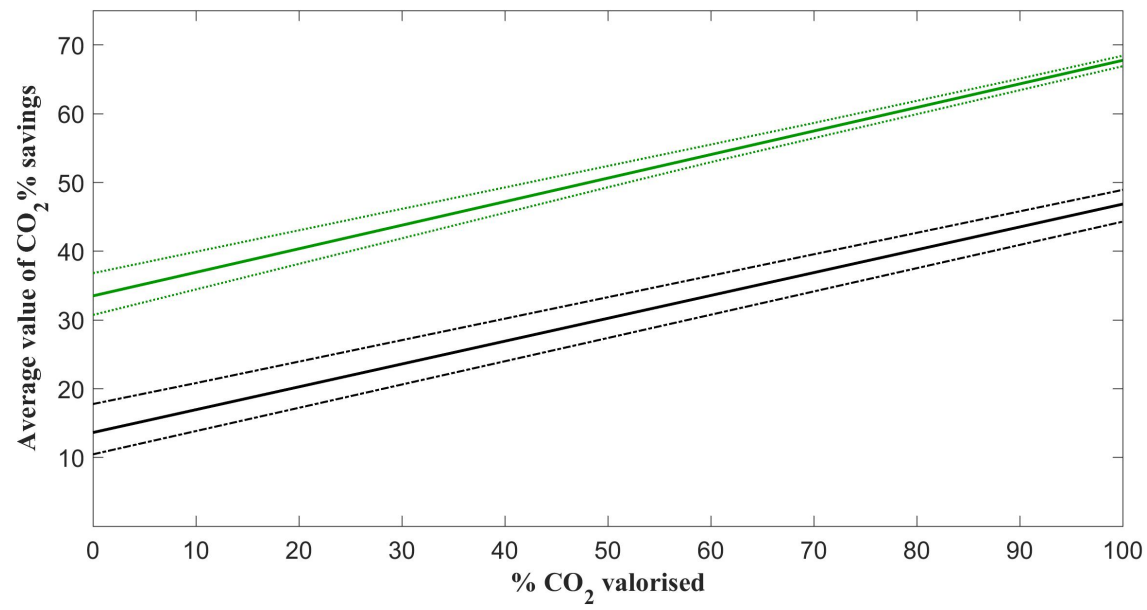

Figure 6: The lower lines represent base case: average value of $\mathrm{CO}_{2} \%$ savings with continuous line and related minimum and maximum with line '-.'; The upper lines represent case with renewable energy: average values of $\mathrm{CO}_{2} \%$ savings with continuous line and related minimum and maximum with line '...' . 


\section{Conclusion}

Syngas compositions, achieved from systematic modelling of gasification for each RDF composition belonging to the defined range of variability, result satisfactory in agreement with measurements from industrial plant. Thus, reliability of the developed model is proven enough to became a useful tool for prediction of syngas composition. The extended analysis of syngas composition variability on downstream steps required for methanol production allows to recognize a meaningful parameter characterizing feedstock composition, namely RDF's LHV, which mostly influences yields and consumptions of the overall WtM process. For this reason, to consider waste composition variability in the preliminary process design steps, LHV can be taken as the primary parameter. However, for the definition of process steps that requires a higher degree of detail, the application of the developed simulation tool, able to take into account all parameters related to variable composition, becomes meaningful. To underline the positive impact of the proposed WtM process, environmental benefit of conversion of waste into methanol rather than energy has been assessed. Average $\mathrm{CO}_{2} \%$ savings is evaluated being equal to $14 \%$, in the worst case with not further application for recovered $\mathrm{CO}_{2}$, and to $35 \%$ in the opposite case. Moreover, in the future optic of using power produced by renewable sources this value will raise up to $68 \%$.

\section{References}

Agovino, M., Ferrara, M., Garofalo, A., 2016. An exploratory analysis on waste management in italy: A focus on waste disposed in landfill. Land Use Policy 57, 669681. 
Akdağ, A.S., Atımtay, A., Sanin, F., 2016. Comparison of fuel value and combustion characteristics of two different rdf samples. Waste management 47, 217-224.

Antonetti, E., Iaquaniello, G., Salladini, A., Spadaccini, L., Perathoner, S., Centi, G., 2017. Waste-to-chemicals for a circular economy: The case of urea production (waste-to-urea). ChemSusChem 10, 912-920.

Aracil, C., Haro, P., Giuntoli, J., Ollero, P., 2017. Proving the climate benefit in the production of biofuels from municipal solid waste refuse in europe. Journal of Cleaner Production 142, 2887-2900.

Beckmann, M., Pohl, M., Bernhardt, D., Gebauer, K., 2012. Criteria for solid recovered fuels as a substitute for fossil fuels-a review. Waste Management \& Research 30, 354-369.

Begum, S., Rasul, M., Akbar, D., 2014. A numerical investigation of municipal solid waste gasification using aspen plus. Procedia Engineering 90, 710-717.

Beigl, P., Lebersorger, S., Salhofer, S., 2008. Modelling municipal solid waste generation: A review. Waste management 28, 200-214.

Bergfeldt, B., Tomasi Morgano, M., Leibold, H., Richter, F., Stapf, D., 2018. Recovery of phosphorus and other nutrients during pyrolysis of chicken manure. Agriculture 8, 187.

Consonni, S., Viganò, F., 2012. Waste gasification vs. conventional waste-to-energy: A comparative evaluation of two commercial technologies. Waste management 32, $653-666$.

Couto, N., Rouboa, A., Silva, V., Monteiro, E., Bouziane, K., 2013. Influence of the 
biomass gasification processes on the final composition of syngas. Energy Procedia $36,596-606$.

De Falco, M., Iaquaniello, G., Centi, G., 2013. $\mathrm{CO}_{2}$ : a valuable source of carbon. Springer.

Devi, L., Ptasinski, K.J., Janssen, F.J., 2003. A review of the primary measures for tar elimination in biomass gasification processes. Biomass and bioenergy 24, 125140.

Di Maria, F., Contini, S., Bidini, G., Boncompagni, A., Lasagni, M., Sisani, F., 2016. Energetic efficiency of an existing waste to energy power plant. Energy Procedia $101,1175-1182$.

Doherty, W., Reynolds, A., Kennedy, D., 2013. Materials and processes for energy: communicating current research and technological developments. Dublin Institute of Technology. chapter Aspen plus simulation of biomass gasification in a steam blown dual fluidised bed. pp. 212-220.

Energy research Centre of the Netherlands, . Phyllis2 database for biomass and waste. Energy research Centre of the Netherlands. URL: https://www.ecn.nl/ phyllis2.

Enerkem s.r.l., . Biofuels and green chemicals. Enerkem S.r.l. URL: http://enerkem. com/biofuels-and-green-chemicals/.

Fulcrum Bioenergy, . Sierra biofuel plant. URL: https://fulcrum-bioenergy.com/ facilities/.

Gagliano, A., Nocera, F., Bruno, M., Cardillo, G., 2017. Development of an 
equilibrium-based model of gasification of biomass by aspen plus. Energy Procedia 111, 1010-1019.

Gallucci, F., Basile, A., Drioli, E., 2007. Methanol as an energy source and/or energy carrier in membrane processes. Separation \& Purification Reviews 36, 175-202.

Galvagno, S., Casu, S., Casciaro, G., Martino, M., Russo, A., Portofino, S., 2006. Steam gasification of refuse-derived fuel (rdf): influence of process temperature on yield and product composition. Energy \& fuels 20, 2284-2288.

Ghisellini, P., Cialani, C., Ulgiati, S., 2016. A review on circular economy: the expected transition to a balanced interplay of environmental and economic systems. Journal of Cleaner Production 114, 11-32.

Grabow, L., Mavrikakis, M., 2011. Mechanism of methanol synthesis on cu through co2 and co hydrogenation. Acs Catalysis 1, 365-384.

Hajinezhad, A., Halimehjani, E.Z., Tahani, M., 2016. Utilization of refuse-derived fuel (rdf) from urban waste as an alternative fuel for cement factory: A case study. Int. J. Renew. Energ. Res 6, 702-714.

Hašková, S., 2017. Holistic assessment and ethical disputation on a new trend in solid biofuels. Science and engineering ethics 23, 509-519.

Hittinger, R.C., 1988. Evaluation of data on higher heating values and elemental analysis for refuse-derived-fuels. National Waste Porcessing - Conference Discussion

Iaquaniello, G., Centi, G., Salladini, A., Palo, E., Perathoner, S., Spadaccini, L., 2017. Waste-to-methanol: Process and economics assessment. Bioresource Technology 243, 611-619. 
Iaquaniello, G., Salladini, A., 2017. A process and relating apparatus to make pure bio- methanol from a syngas originated from wastes gasification. Google Patents. URL: https : //patents.google.com/patent/W02018134853A1/. international Publication Number, WO2018134853A1.

InEnTec, . Pem process details. URL: http://www.inentec.com/pem-technology/ process-details/.

Institute of Gas Technology, 1978. Coal conversion systems technical data book.

Intergovernmental Panel on Climate Change, 2014. Fifth assessment report.

Jarungthammachote, S., Dutta, A., 2007. Thermodynamic equilibrium model and second law analysis of a downdraft waste gasifier. Energy 32, 1660-1669.

Lapola, D.M., Schaldach, R., Alcamo, J., Bondeau, A., Koch, J., Koelking, C., Priess, J.A., 2010. Indirect land-use changes can overcome carbon savings from biofuels in brazil. Proceedings of the national Academy of Sciences 107, 3388-3393.

Lin, K.S., Wang, H.P., Liu, S.H., Chang, N.B., Huang, Y.J., Wang, H.C., 1999. Pyrolysis kinetics of refuse-derived fuel. Fuel Processing Technology 60, 103-110.

Mahishi, M.R., Goswami, D., 2007. Thermodynamic optimization of biomass gasifier for hydrogen production. International Journal of Hydrogen Energy 32, 3831-3840.

Mardoyan, A., Braun, P., 2015. Analysis of czech subsidies for solid biofuels. International Journal of Green Energy 12, 405-408.

Maroušek, J., Kolář, L., Vochozka, M., Stehel, V., Maroušková, A., 2018a. Biochar reduces nitrate level in red beet. Environmental Science and Pollution Research 25, $18200-18203$. 
Maroušek, J., Stehel, V., Vochozka, M., Maroušková, A., Kolář, L., 2018b. Postponing of the intracellular disintegration step improves efficiency of phytomass processing. Journal of cleaner production 199, 173-176.

Matsakas, L., Gao, Q., Jansson, S., Rova, U., Christakopoulos, P., 2017. Green conversion of municipal solid wastes into fuels and chemicals. Electronic Journal of Biotechnology 26, 69-83.

McKay, G., 2002. Dioxin characterisation, formation and minimisation during municipal solid waste (msw) incineration. Chemical Engineering Journal 86, 343-368.

Mills, K., 1986. Estimation of physicochemical properties of coal slags and ashes, ACS Publications.

Montejo, C., Costa, C., Ramos, P., del Carmen Márquez, M., 2011. Analysis and comparison of municipal solid waste and reject fraction as fuels for incineration plants. Applied Thermal Engineering 31, 2135-2140.

Patra, T.K., Sheth, P.N., 2015. Biomass gasification models for downdraft gasifier: A state-of-the-art review. Renewable and Sustainable Energy Reviews 50, 583-593.

Pérez-Fortes, M., Schöneberger, J.C., Boulamanti, A., Tzimas, E., 2016. Methanol synthesis using captured co2 as raw material: Techno-economic and environmental assessment. Applied Energy 161, 718-732.

Pohl, M., Beckmann, M., Gebauer, K., 2008. Characterisation of refuse derived fuels in view of the fuel technical properties, in: The 8th European Conference on Industrial Furnaces and Boilers (INFUB-8).

Ramzan, N., Ashraf, A., Naveed, S., Malik, A., 2011. Simulation of hybrid biomass 
gasification using aspen plus: A comparative performance analysis for food, municipal solid and poultry waste. Biomass and Bioenergy 35, 3962-3969.

Rostrup-Nielsen, J.R., 2000. New aspects of syngas production and use. Catalysis today $63,159-164$.

Rubin, E.S., Chen, C., Rao, A.B., 2007. Cost and performance of fossil fuel power plants with co2 capture and storage. Energy policy 35, 4444-4454.

Schuster, G., Löffler, G., Weigl, K., Hofbauer, H., 2001. Biomass steam gasificationan extensive parametric modeling study. Bioresource technology 77, 71-79.

Senior, K., Mazza, A., 2004. Italian "triangle of death" linked to waste crisis. The lancet oncology 5, 525-527.

Shahhosseini, H.R., Iranshahi, D., Saeidi, S., Pourazadi, E., Klemeš, J.J., 2018. Multi-objective optimisation of steam methane reforming considering stoichiometric ratio indicator for methanol production. Journal of cleaner production 180, 655665.

de Souza-Santos, M.L., 2010. Solid Fuels Combustion and Gasification: Modeling, Simulation. CRC Press.

Swain, P.K., Das, L., Naik, S., 2011. Biomass to liquid: a prospective challenge to research and development in 21st century. Renewable and Sustainable Energy Reviews $15,4917-4933$.

ThermoChem Recovery International, . Steam-reforming gasification. URL: https : //tri-inc.net/steam-reforming-gasification/.

Zainal, Z., Ali, R., Lean, C., Seetharamu, K., 2001. Prediction of performance of a 
downdraft gasifier using equilibrium modeling for different biomass materials. Energy conversion and management 42, 1499-1515.

Zhang, Q., Dor, L., Zhang, L., Yang, W., Blasiak, W., 2012. Performance analysis of municipal solid waste gasification with steam in a plasma gasification melting reactor. Applied energy 98, 219-229.

Zhang, Q., Wu, Y., Dor, L., Yang, W., Blasiak, W., 2013. A thermodynamic analysis of solid waste gasification in the plasma gasification melting process. Applied energy 112, 405-413. 